\title{
Towards a Functional African State: Bridging the Gap Between the State and the People
}

Wale Are Olaitan*

\begin{abstract}
This paper analyses the contribution of the African state to the problems of development in Africa. I argue that the nature of the modern African state, inherited from the colonial state, is inherently oppressive and dysfunctional and that a fundamental change in the nature of the state is required in order to reposition the continent developmentally and liberate the energies of the African people. The existing nature of the African state disposes it toward a negative relationship with the people, leading to a gap in the relationship between the people and the state. This gap has to be bridged in order for the state to contribute positively to the developmental process in the interests of the people. I argue in particular that relying on structural adjustment, electoral democracy and other forms of reform to bridge this gap is misplaced because these reforms do not seek to change the nature of the African state. The people cannot liberate themselves from state oppression or make the state accountable through elections conducted and presided over by the existing negative structures of the state. Only a fundamental change in the nature of the state can accomplish this.
\end{abstract}

\section{Résumé}

Cette étude analyse la contribution de l'état Africain aux problèmes de développement en Afrique. Je soutiens que la nature de l'état Africain moderne, hérité de l'état colonial, est oppressive et dysfonctionnelle et qu'un changement fondamental de cette nature est requis afin de repositionner le continent sur le plan du développement et de libérer les énergies du peuple africain. La nature actuelle de l'état Africain l'incline vers un rapport négatif avec le peuple, créant ainsi un fossé entre

* Department of Political Science, Olabisi Onabanjo University, Ago-Iwoye, Nigeria. Email: anujah@yahoo.com 
eux. Ce fossé doit être comblé afin que l'état contribue positivement au processus de développement dans l'intérêt du peuple. Je démontre notamment que dépendre de l'ajustement structurel, de la démocratie électorale et d'autres formes de réformes pour combler ce fossé est déplacé car ces réformes ne visent pas à changer la nature de l'état Africain. Le peuple ne peut pas se libérer de l'oppression de l'état ou responsabiliser l'état par le biais d'élections effectuées et présidées par les structures étatiques négatives existantes. Seul un changement fondamental de la nature de l'état peut accomplir cela.

\section{Introduction}

The reality of underdevelopment in Africa is undeniable. There is massive lack of infrastructure, the people lack proper and adequate food and living conditions are so abject that that more than half of the people in the continent survive below the poverty line. Indeed Africa is constantly presented as the typical face of underdevelopment, with images of malnourished and dying children and parents, and the continent appears to depend on aid and donations just to keep up the appearance of decent humanity. Therefore the issue in Africa is not the reality of underdevelopment, but how to change that reality by bringing real and meaningful development to the continent (Mkandawire and Olukoshi 1995; Nabudere 2000; Tipoteh 2000).

However the reality of underdevelopment in Africa is not only about the impoverished living conditions of the people. The continent also suffers from impoverished institutions. This is not because of lack of resources-Africa is well-endowed with both human and natural resources-but because of a combination of institutional failures which have to be corrected for the continent to achieve development. Chief among these institutional problems is the state, which is ultimately responsible for the underdeveloped nature of Africa if only by virtue of providing the framework for every organisation within its jurisdiction (Laski 1982). The state is the basic modern organisational condition for existence, and it must follow that the state will influence all the actions within its jurisdictional competence. This is the sense in which the African state is a major component of developmental failure in Africa, suggesting that the problems of the state have to be addressed as part of the solution to the problems of underdevelopment on the continent (Yahaya 1989; Bangura et al. 1992).

The conditions of existence of the state in Africa are non-functional, if not dysfunctional, judging by the inability of the state to even main- 
tain reasonable and effective control over its territory. The African state exists more as a juridical entity at the mercy of international recognition, not through the affirmation of its people. It is an exploitative and oppressive force rather than an instrument for the people's welfare and edification (Bratton 1989; Clapham 1996). The truth is that the African state at present functions as an entity apart from the people and is thus enmeshed in a crisis of significance and legitimacy as it struggles to justify its existence. Only to the extent that this crisis of legitimacy is successfully confronted can the African state become a force for development on the continent.

The crisis of legitimacy and relevance means that state structures are continually contested, such that the African landscape is replete with wars and other violent struggles to gain control of the contested structures. This reality is not conducive to real development and imposes extra burdens on the people. The context of the state therefore has to be made more conducive to development in Africa. This requires a radical transformation of the state to make it functional and people-oriented. My argument is that the present non-functional state in Africa is a negative influence on development processes and has to be changed to ensure that the state provides an enabling environment for real development. The challenge of making the African state a functional and development-promoting entity is the issue addressed in this paper. I explore in particular the different strategies for bridging the gap between the state and the people, given that an abiding characteristic of the African state's dysfunctionality is its alienation from the people.

\section{The Gap Between the State and the People in Airica}

The African state is remarkable for its enormous and untrammeled power over its people, even as it set itself apart from the people. Perhaps deriving its essential conception from its colonial pedigree, the state in Africa operates as an imposed power over and above society, surviving by the exploitation of the people. Rather than operating as an organ of society for the protection and promotion of the people's interests, the state acts as an organ apart from society, surviving from the oppression of the people. This is the sense in which the African state has been described as a 'leviathan' state (Callaghy 1988) not answerable to any check or countervailing force due to 'its lack of autonomy, the immen- 
sity of its power, its proneness to abuse and lack of immunity against it' (Ake 1996:7).

The untrammeled power of the state in Africa covers the entire gamut of life and societal operations. Claude Ake (1996: 6-7), for instance, describes the workings of the African state thus:

There is hardly any rule of law, no plausible system of justice, no transparency. The coercive institutions of the state are above the law, civil society is below it, ordinary people are out of sight, far beyond its protection. The judiciary is dissociated from justice, and the bureaucracy is oppressive and arbitrary. The [African] state, like the colonial state before it, turns on the calculus of strength.

Such a state does not and cannot care about its people and would not make their interests its concern; it is a state in which power is exercised for the sake of power and not for the benefit of the people. This state is a predatory one, existing for the oppression and exploitation of its own people through the deployment of 'overdeveloped' structures which overwhelm all other structures in the society.

Ironically the exercise of power by the state in Africa does not assure obedience to its rules and regulations or the ability to fully institutionalise itself. As already noted, the African state survives on the 'calculus' of strength and the use of force. It is not in a position to generate an affinity with the people because it does not work for the interest of the people. In response the people of Africa have learnt to treat the state with disdain. They correctly see the state as an oppressive entity and take the necessary steps to protect themselves from it where possible. Since state and society in Africa are placed in contradiction by virtue of the preference of the state to prey on the society, society is not in a position to have a meaningful relationship with the state. As a result the state cannot fully and successfully institutionalise itself or turn its power into obedience. And with the state relying on force in order to perpetuate its oppression, society is at liberty to relate to it as a conqueror entity, something to be feared and obeyed where necessary and to be undermined wherever this is possible. As Ake (1996: 8-9) observes:

when most of us encounter what answers to the state only as a predatory force on the rampage, when those who are supposed to defend us have turned their arms against us and never grant us any respite from exploitation ... . is it any wonder that we don't have a public morality, 
that we think nothing of subverting the state, stealing from it, cheating it in every way and refusing to pay taxes?

This means that the enormously powerful state in Africa is also remarkably weak and is not able to tease out a meaningful relationship with society (Chazan 1988). This is the sense in which the African state has also been described as a 'lame' leviathan unable to translate its enormous power into routine obedience (Callaghy 1988). The chasm between the state and society in Africa means that the state does not exist for the promotion and protection of the interests of the people, nor do the people take the state as their own or feel concerned about it. The people in fact see the state as an impediment and try to work out their survival in spite of it. The state in turn sees society only as an entity to be plundered and exploited.

The implication is that neither the state nor society in Africa benefits from a relationship that should ordinarily be rewarding to them, as the state lacks full institutionalisation. Ideally state and society should function in a symbiotic relationship, with the state caring for the interests of society and society supplying the wherewithal for the functions of the state. However, the state in Africa has to routinely dissipate its power and energy on the use of force in order to exploit and accumulate resources from the society. On the other hand society is routinely denuded of resources through exploitation by the state. Thus the reality of the gap between the state and the people in Africa not only speaks to an existing chasm; it also points to an undesirable situation that has to be confronted and changed if the two entities are to benefit from a more productive relationship in which a functional state becomes the benchmark for real development in society.

\section{Bridging the Gap: The Limits of Structural Adjustment and Electoral Democracy}

The reality of the gap between the state and society in Africa has not really been contested vigorously in spite of attempts to underplay its importance to the development process by some analysts, particularly those representing the notion of rolling back the state (Kawonise et al. 1998). The general consensus has been that the state in Africa has been inefficient and therefore has to be made efficient and effective in order to make any meaningful impact. This should happen even if there is disagreement about what it would take to achieve a functional state in Africa. The Bretton Woods institutions, for instance, believe that the 
African state has to be strengthened in order to provide a framework for the implementation of their reform agenda. However this will only help the state consolidate its overarching powers, thus deepening its relation of force to the people. As Beckman (1992: 83) puts it, the 'focus of the World Bank is on the restructuring of the African state in order to make it supportive of its long-term strategy for the liberation of market forces ... [in] African society'. Thus it is not surprising that the restructuring in Africa carried out under the aegis of the Bretton Woods institutions produced more negative reactions as the people responded to the deepening intensity of state oppression which this restructuring effected.

In the era of structural adjustment and deregulation under the aegis of the 'limited state', the African state was expected to become more efficient by presiding over the imposition of market forces that exposed the people more fully to the exploitative sting of international business and its local agents while pretending to concentrate on 'good governance', that is, the strengthening of the repressive apparatus of the state in order to cope with the negative reactions of the people to the impoverishing effects of structural adjustment programmes. This 'reform' of the state thus did not bridge the gap between it and the people; the state only strengthened its forces against the people and their agitation. The continuation of the gap explains why structural adjustment in Africa was 'characterised by worsening living conditions and the intensification of demands for improved living standards' by the people (Mkandawire and Olukoshi 1995; Tipoteh 2000).

This scenario required further efforts at reforming the African state in order to give a semblance of affinity between it and the people. One of the ways these efforts manifested themselves was in the attempt to impose 'democratisation' on the processes of the state. The case was made that the people and the state should work together and that this would bridge the gap between them, with the people having a working control over the activities of the state through democratic processes, largely through elections. The democratisation process in Africa therefore concerned itself mainly with the conduct of elections and the establishment of as many political parties as possible. Many African countries went through the process of conducting elections in order to give a new order and perspective to the existence of the state. From this perspective elections are expected to help guarantee control of the people over their own affairs and ensure that they are in a position to install governments that serve their needs. A government that is accountable 
to the people should in theory run the activities of the state in a peopleoriented and people-friendly manner, and the end result should be a state that relate positively to its people.

As a starting point electoral democratisation had the potential of redirecting the affairs and essence of the state positively towards the people:

The legality of the political opposition, enlargement of the public space through a plural press and a rich array of civic organisations ... [together with the] gradual abandonment of undue persecution of conscientious objectors, etc. are important preconditions for the more elaborate, more arduous and long-term task of reconstituting and transforming the political ... institutions and political cultures (Amuwo 1999: 16).

The implication of this position is that electoral democracy should help to remove the continuing oppressive activities of the state by turning the state over to the control of the people and thus ensuring that the gap between the people and the state is effectively closed. This is the sense in which political reform was to accompany the economic reforms carried out under structural adjustment, with the two reforms ultimately delivering real development for the people and impacting positively on their living conditions (Kawonise et al., 1998).

Unfortunately the immense expectations invested in electoral democracy do not reckon with the guiding disposition of the state toward all acts within its territory. This means that electoral democracy has to be conceptualised and contemplated ultimately within the context dictated by the constricting nature of the state in Africa. It should not be assumed that a context that is anti-people would ordinarily yield itself to control by the people. Thus Claude Ake (1996) argues that democratisation in Africa can only be real and meaningful if it seeks to address and change the constricting context of the state. Unfortunately, as Ake notes (1996: 6), democratisation in Africa manifesting as electoral democracy has been 'conducted with no questions asked about the character of the state, as if it has no implication for democracy'. Since virtually every act falls within the purview of the context established by the state, elections too will reflect the overarching and overriding nature of the state and its anti-people disposition. Elections will never deliver control of the state to the people within this context.

Thus it is not surprising that elections under the context of electoral democratisation do not differ significantly from the manipulative trend 
that is consistent with the oppressive nature of the state in Africa. They give voters 'only a choice between oppressors' and result in 'voting that never amounts to choosing', as elections continue to be 'manipulated through rules of the game that reduce the chances for fairness and by electoral fraud' (Ake 1996). This is why manipulation of elections has been a key feature of the 'democratization' process in Africa, leading to disputed results in Côte d'Ivoire, Liberia, Sierra Leone, Nigeria, Kenya, Zimbabwe, Sudan, Togo and Malawi, with the manipulations sometimes serving as a basis for further disputes and violent conflicts. Within this context the existing gap between the state and the people will necessarily continue, and the people will be further impoverished by avoidable conflicts engendered by disputed elections.

Electoral democracy does not address the fundamental nature of the gap between the African state and the people caused by the nature of the state itself. The gap exists because of the oppressive nature of the state, and it is only to the extent that this oppressive nature is confronted and changed that a meaningful relationship can be contemplated between the state and the people. In maintaining an adversarial relationship with the state, the people are only reacting to the state's exploitative nature. A more congenial relationship can be achieved only if the state changes its nature and relates in a more positive way to the people. This situation means that working for a positive relationship between the state and the people entails more than elections; it must involve a direct assault on the nature of the state itself. A new conception of the state is needed in which the state exists for the benefit of the people. Achieving this must include free and fair elections to ensure that governments are accountable to the people but cannot be limited to this. The overall context of state-society relations has to be reconstituted to underline the centrality of the people.

Electoral democracy is not able to significantly change the existing gap between the state and the people in Africa because it does not address the nature of the state. It seeks to change the relationship between the people and the state without changing the nature of the state itself. But only by addressing the oppressive and exploitative nature of the state can the gap between the state and the people be confronted. And only by bridging this gap can a functional and meaningful state emerge to direct the process of real development in Africa. 


\section{Lessons from the Decolonisation Struggle}

The oppressive nature of the state in Africa is related to its pedigree in the colonial state, which saw its essence as subjugating and exploiting the people. The exploitative character of the colonial state was consistent with the subjugating and exploitative essence of colonialism itself. Since the colonial state was set up principally to further the interests of colonialism, it naturally embodied and replicated the essence of colonialism. Therefore it was not inconsistent for the colonial state to see the subjugation of the people in the colonies as its prime objective. The reaction of the people in the colonies was also consistent with this notion. They saw the colonial state as an entity to be actively resisted, and it was in this context that the spirit of nationalism and the struggle for decolonisation was born among the colonised peoples. Therefore the colonial state was not just an entity above the society and existing for the subjugation of its society, it was a state that was also actively resisted by the people (Callaghy 1988).

Thus there was never a time when the colonial state was accepted; the people appropriately saw it as an alien and negative entity that should be combated and destroyed. The question was never how to reform the colonial state but how to dislodge it, as is confirmed by the consistent rejection of any midway deal by nationalists in Africa. The colonial state, given its nature, could not be reformed. Only by replacing it could the people get back their true identity as a nation and escape the subjugating essence of a constricting entity. This was the whole essence of the decolonisation struggle. The importance and value of this struggle could only be measured in relation to the nature and essence of the state it was directed against. In reality the struggle was defined by the subjugating essence of the colonial state, and the strategies and tactics deployed were consistent with the objective of destroying and replacing the colonial state.

Because of the clear objective of the decolonisation struggle, those involved realised the duties and responsibilities it imposed on them and therefore enunciated strategies and tactics that would not compromise the objective. The nature of the colonial state was the prime object of their attack, and they realised that the mass of the people had to be mobilised against it. The success of the decolonisation struggle was owing to two principal ingredients of the struggle itself: the fact that the struggle was to dislodge the colonial state, not reform it, and the enlistment of the mass of the people into the struggle as a reflection of 
its totalising essence. The nationalists were very clear that no compromise could be struck with an alienating and subjugating state. Everywhere in Africa the goal of the decolonisation struggle was to dislodge the colonial state though direct engagement that sought to fundamentally change the nature of the state. Even when nationalists were offered tempting arrangements to reform the colonial apparatus, as in the French colonies where the colonised people were offered citizenship of the colonialist state, they insisted on full independence rather than accommodation with colonialism.

In addition the conception of the struggle as one to be waged by the people themselves through mass mobilisation ensured that the leadership could not betray the people. The people were fully supportive of the struggle and had become its main ingredient. Within this context the people were the motive force of the struggle and the ones who determined its eventual direction, the liberation of the people from the subjugation of the colonial state. The decolonisation struggle achieved its aim in spite of setbacks and obstacle because it was based on the determination of the people to dislodge the colonial state, not on the say-so of a few leaders or those who wanted to represent the people. It was therefore logical for the people to push the struggle to its conclusion; it was not a struggle that could be derailed by the compromises of the leadership. The lesson of the struggle against the colonial state is therefore to invest the people with the responsibility for their own struggle and not seek to struggle for them. Leaders can engage in the conscientisation and mobilisation of the people, tasks which the nationalist leaders performed admirably, but the ultimate responsibility belonged with the people. In the last analysis the direct participation of the people in their own struggle is essential for success, and this is particularly important where the very nature of the oppressive state has to be combated.

\section{Conironting the Gap Between the People and the State}

The gap between the state and the people in Africa works mostly to the disadvantage of the people, as they are unable to live worthwhile lives under the constraints imposed by the debilitating existence of the state. The state on the other hand is also harmed; it cannot achieve a maximally beneficial existence under the existing gap between it and the people. However those that are in control of the apparatus and structures of 
the state obviously derive advantages from the use of state structures to exploit the people and therefore are not interested in closing the existing gap, as it works well for them. This is also the reality the nationalists confronted at independence when the colonial state was dislodged and the new independent African state was put in place. Those who supplanted the colonialists preferred to perpetuate the exploitation associated with the colonial state. The colonial state was dislodged, but was then perpetuated by the new indigenous rulers. Thus the postcolonial state is in reality the colonial state in another guise, continuing the exploitative tendencies of the colonial state and reflecting and maintaining the gap that existed between the colonial state and the people.

What is important is that the people are the ones bearing the major brunt of the state's negative effects, and they are therefore the ones to benefit from the gap being bridged. By contrast those presiding over the state generally prefer to continue to benefit from the gap. Thus only the people can be relied on to be interested in changing the existing situation, and nobody should take African rulers seriously when they speak about their concern with changing the nature of the state to make it benefit the people; oppressors always speak of helping the oppressed. In any case, given that the post-colonial state is no more than a shadow of the colonial state, it is clear that it is not susceptible to reform; it has to be dislodged. It is impossible to reform an entity with such a deficient nature. This is why all the efforts in the past at reforming the African state have come to nothing. These efforts have always emanated from those controlling the levers of power, who naturally prefer to continue to sell unworkable ideas and strategies in order to preserve the exploitation of the people.

The only realistic way to bridge the gap is to change the nature of the state. This requires a fundamental reworking of the essence and conditions of existence of the state. Mere reform of the state in Africa will never bridge the gap between it and its people. This can only be attained by dislodging the existing state and replacing it with a new conception of the state consistent with serving the interests of the people. This was the strategy used in combating the colonial state, and it should be the strategy where traits of the colonial state continue to dominate in the post-colonial state. The fact that those who are presiding over the state apparatus now are indigenous Africans should not be used to justify recourse to reform where fundamental change is required. The bottom line is that the existing nature of the state is not 
conducive to a meaningful relationship with the people. The existing nature of the state dictates its exploitation of the people, and the only way to proceed to a meaningful relationship with the people is to institute a new state that would emerge by replacing the existing one, not by reforming it.

Obviously the task of instituting a new state has to devolve on the people, as they are the ones negatively affected by the existing situation. Thus Campbell (2005) argues that 'only direct action on the part of the people, [their] own perception of what is possible, ... can produce change'. To accomplish this, the people have to be invested with confidence to work for the actualisation of the required change, rather than being consigned to the background while some seek change on their behalf. The truth is that those who are benefiting from the present gap will only succumb to pressure from the people en masse, as no power can withstand the conscious and deliberate desire of the people for change. Therefore it is important for the people to be conscientised to the power residing in them as far as change is concerned, such that they will get ready to take their destiny in their own hands and work for change themselves. The fact that those who are presiding over the state now have deepened their hold on the enormous powers of the state and that these can be used to frustrate the aspirations of the people should not vitiate the enormous potential in the ranks of the people themselves. In any case ultimate power resides in the people, and the capacity of the people to change their own conditions has never been doubted (Campbell 2005). Ultimate victory is assured as long as the people are committed to their struggle for change and can see the benefits that change will bring.

What is required is for the people to have the right kind of consciousness. Those who believe in the people and their cause can achieve this through deliberate conscientisation. The terrible living conditions of the people predispose them to desire a positive change. All they need is help to believe in their own power to effect such change in spite of the overbearing presence of the state. The need for a functional state that will bridge the gap between it and the people in Africa is not just about strengthening the state; it is a developmental concern that touches ultimately on the living conditions of the people. This is why the ultimate duty is that of the people, and the right strategy for achieving change is to exhort the people to face the challenge of helping themselves. 


\section{Conclusion}

This paper has underlined the contribution of the African state to the problems of development in Africa and argued that a fundamental change in the nature of the state is required as part of the efforts at repositioning the continent developmentally. The existing nature of the African state disposes it toward a negative relationship with the people, leading to a relationship gap between the people and the state. This gap has to be bridged in order for the state to contribute positively to the developmental process in the interests of the people. I have argued that relying on structural adjustment, electoral democracy and other forms of reform to bridge this gap is misplaced because the reform approach does not seek to change the nature of the African state. The people cannot penetrate the locus of the existence of the state through elections that are conducted and presided over by the existing negative structures of the state; what is required is fundamental change in the nature of the state.

Bridging the gap between the state and the people in Africa, especially in light of the experience of the decolonisation struggle, which massively involved the people and made fundamental change rather than reform its objective, must go beyond elections and involve the people in the search for appropriate strategy and tactics with which to achieve their own emancipation from the exploitative clutches of the state. Indeed the issue of strategy and tactics should not be contemplated or approached outside of the capacity of the people to effect change in their own conditions, as change cannot be forced on the people. The people must be the architects of their own change and should be assisted through appropriate conscientisation efforts to come to full realisation of the enormous potential they themselves possess to rescue themselves from the exploitation of the state. The extent to which the people will rise to this responsibility depends ultimately on the level of commitment that could be derived from their conscientisation and the level of deployment of this commitment toward achieving the objective of changing the nature of the state in Africa. 


\section{References}

Ake, C., 1996, Is Africa Democratising? Lagos: Centre for Advanced Social Sciences (CASS) and Malthouse Press.

Amuwo, K, 1999, 'Rethinking the Linkage between the Market and Democracy in Africa', Nigerian Journal of Social and Management Sciences, Vol. 2, No. 1.

Bangura, Y., Gibbon, P., and Ofstad, A., eds., 1992, Authoritarianism, Democracy and Adjustment: The Politics of Economic Reform in Africa, Uppsala: Nordiska Afrikainstitutet.

Beckman B., 1992, 'Empowerment or Repression: The World Bank and the Politics of African Adjustment', in Y. Bangura, P. Gebbon and A. Ofstad, eds., Authoritarianism, Democracy and Adjustment: The Politics of Economic Reform in Africa, Uppsala: Nordiska Afrikainstitutet.

Bratton, M., 1989, 'Beyond the State: Civil Society and Associational Life in Africa', World Politics, Vol. 41, No. 3.

Callaghy T. N., 1988, 'The State and the Development of Capitalism in Africa: Theoretical, Historical and Comparative Reflections', in D. Rothchild and N. Chazan, eds., The Precarious Balance: State and Society in Africa, Boulder: Westview Press.

Campbell, H. G., 2005, 'Philosophy and Praxis: The Life and Work of Walter Rodney', paper presented at the AAPS Biennial Congress, Cairo.

Chazan, N., 1988, 'Patterns of State-Society Incorporation and Disengagement in Africa', in D. Rothchild and N. Chazan, eds., The Precarious Balance: State and Society in Africa, Boulder: Westview Press.

Clapham C., 1996, Africa and the International System: The Politics of State Survival, New York: Cambridge University Press.

Kawonise S., Adefulu, R., Olaitan, W., and Amuwo, K., 1998, Economic Deregulation, Occupational Groups and Prospects of Popular Participation in Nigeria, Ibadan: NISER and National Research Network on Liberalisation Policies in Nigeria.

Laski, H. J., 1982, A Grammar of Politics, London: Unwin Hyman.

Mkandawire, T. and Olukoshi, A., 1995, Between Liberalisation and Oppression: The Politics of Structural Adjustment in Africa, Dakar: CODESRIA.

Nabudere, D. W., ed., 2000, Globalisation and the Post-Colonial African State, Harare: AAPS Books.

Tipoteh, T., 2000, 'Globalisation and Development', in D. W. Nabudere, ed., Globalisation and the Post-Colonial African State, Harare: AAPS Books.

Yahaya, A. D., 1989, The Developmental State in the Process of Transformation: The Implication for the Political Science Discipline, Ibadan: NPSA Annual Lecture 